\title{
Laporan Kasus: Corneal Ulcer karena Secondary Trauma Keratoconjuntivitis Sicca pada Kucing
}

\author{
Case Report: Corneal Ulcer due to Secondary Trauma of \\ Keratoconjuntivitis Sicca in Cat \\ Oman Setiyanto $^{1 *}$, Miranti Verdiana Aizah ${ }^{1}$, Khoirus Viestaria$^{1}$, Ajeng Aeka \\ Nurmaningdyah ${ }^{1}$ \\ ${ }^{1}$ Sarjana Kedokteran Hewan, Kandidat Dokter Hewan, Sarjana Fakultas Kedokteran \\ Hewan, Universitas Brawijaya \\ *email: omansetiyanto@gmail.com,ppdhgel5@gmail.com
}

\begin{abstract}
ABSTRAK
Berbagai penyakit mata yang pernah ditemukan pada kucing diantaranya seperti corneal ulcer. Metode pemeriksaan yaitu inspeksi mata keseluruhan, schirmer tear test (STT), dan fluorescein test. Hasil penekanan palpebrae didapat konsistensi mata kanan yang keras disertai discharge berlebih. Hasil pemeriksaan fluorescein test yaitu warna hijau paper strip masih menempel pada mata meskipun sudah dibasuh menggunakan $\mathrm{NaCl}$. Nilai STT mata kanan didapatkan $10 \mathrm{~mm} /$ menit dan mata kiri $8 \mathrm{~mm} /$ menit. Terapi yang diberikan adalah antiibiotik tetes mata levofloksacin diberikan 6 kali/hari sebanyak 1 tetes pada kedua mata. Pada mata kanan diberikan pilocarpin HCL 1\% dan diteteskan hanya pada mata kanan satu tetes sebanyak $6 \mathrm{kali} /$ hari, dengan pemberian 10 menit sebelum pemberian antibiotik tetes. Tetes mata Hydroxypropyl methylcellulose diberikan sebanyak $6 \mathrm{kali} /$ hari. Terapi dilakukan sampai minggu ke-3 dan mendapatkan respon kesembuhan yang baik yaitu sudah tidak terlihat chemosis dan membran niktitan, produksi discharge mata berkurang, sudah terdapat respon palpebrae pada mata kiri namun pada mata kanan hanya ada sedikit, namun kornea masih terlihat keruh bilateral. ukuran bola mata kanan mengecil. Hasil STT setelah pengobatan menunjukkan pada mata kanan adalah $15 \mathrm{~mm}$ dan mata kiri $14.5 \mathrm{~mm}$.
\end{abstract}

Kata Kunci: Corneal ulcer, schirmer tear test, levofloksacin, pilocarpin HCL 1\%.

\begin{abstract}
Various eye diseases that been found in cat include corneal ulcers. Examination methods were eye inspection, schirmer tear test (STT), and fluorescein test. The result of palpebrae compression showed consistency of harden-right eye with excessive discharge. The results of the fluorescein test showed that the green paper strip still attached to the eye even though it washed using $\mathrm{NaCl}$. The STT values for the right eye were $10 \mathrm{~mm} / \mathrm{minute}$ and the left eye were $8 \mathrm{~mm} /$ minute. Treatment given was a levofloxacin eye drop antibiotic, administered 6 times/day, 1 drop in both eyes. In the right eye, pilocarpin HCL 1\% was given and dropped only into the right eye one drop 6 times/day, with administration 10 minutes before antibiotic
\end{abstract}


drops. Hydroxypropyl methylcellulose eye drops are given 6 times/day. Therapy was carried out until the 3 rd week and got a result good healing response, chemosis and niktitan membrane were no visible, eye discharge was reduced, had palpebrae response in the left eye but only a little in the right eye, but cornea still looks cloudy bilaterally. the right eye size has decreased. STT results after treatment showed that the right eye was $15 \mathrm{~mm}$ and the left eye was $14.5 \mathrm{~mm}$. Keywords: Corneal ulcer, schirmer tear test, levofloksacin, pilocarpin HCL 1\%.

\section{PENDAHULUAN}

Kucing merupakan hewan kesayangan yang banyak dipelihara oleh manusia karena memiliki tingkah laku yang menggemaskan dan penurut, bahkan sudah dianggap sebagai anggota keluarga sendiri oleh sebagian pemilik hewan. Kucing termasuk dalam jenis hewan karnivora sejati, yang mana sistem pencernaan kucing hanya mampu mencerna unsur pakan hewani secara meknik dan enzimatis. Kucing juga memiliki berbagai daya tarik tersendiri karena keanekaragaman warna bulu, bentuk tubuh, dan mata sehingga banyak dijadikan sebagai hewan peliharaan.

Ulkus kornea merupakan diskontinuitas atau hilangnya sebagian permukaan kornea akibat kematian jaringan kornea. Terbentuknya ulkus kornea diakibatkan oleh adanya kolagenase yang dibentuk oleh sel epitel baru dan sel radang. Gejala dari ulkus kornea yaitu nyeri, berair, fotofobia, blefarospasme, dan biasanya disertai riwayat trauma pada mata. Ulkus kornea yang luas memerlukan penanganan yang $\begin{array}{llll}\text { tepat dan } & \text { cepat untuk } & \text { mencegah } \\ \text { perluasan } & \text { ulkus dan timbulnya }\end{array}$ komplikasi seperti descementocele, perforasi, endoftalmitis, bahkan kebutaan. Ulkus kornea yang sembuh akan menimbulkan jaringan parut kornea dan merupakan penyebab kebutaan nomor dua di Indonesia.

Dry eye syndrome (DES), dikenal juga sebagai keratokonjungtivitis sicca ataudysfunctional tear syndrome, adalah gangguan pada lapisan air mata dengan penyebab multifaktorial yang berpotensi menimbulkan kerusakan pada permukaan mata. DES dapat disebabkan oleh defisiensi air mata atau evaporasi yang berlebihan, yang dapat merusak permukaan okular intrapalpebral dan menimbulkan gejala okular. Dry eye syndrome dipengaruhi banyak faktor, mulai dari inflamasi pada permukaan mata, kelainan kelenjar lakrimal, disfungsi kelenjar meibom, dan defisiensi neurotropik. Kelainan-kelainan tersebut berdampak pada gangguan produksi air mata, meningkatnya evaporasi air mata, dan kualitas air mata yang buruk. 
Gangguan keseimbangan lapisan air mata tersebut lambat laun akan menyebabkan kerusakan pada permukaan mata.

\section{TINJAUAN KASUS}

\section{a. Signalment}

Nama hewan adalah Blacky, jenis hewan kucing, ras domestic short hair (DSH), berwarna hitam, jenis kelamin betina, umur 3 Bulan, berat badan $0,46 \mathrm{~kg}$.

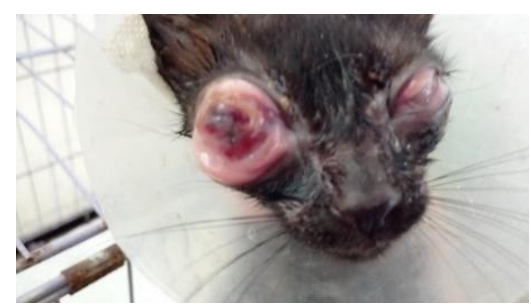

Gambar 1. Kondisi awal kucing "Blacky" (dokumentasi pribadi, 2020).

\section{b. Anamnesa}

Seekor kucing ras domestic short hair (DSH) ditemukan dijalan pada tanggal 1 Februari 2020 dengan kondisi kelopak mata menutup, bengkak, dan banyak discharge basah dan kering disekitar mata kanan dan kiri. Kucing tersebut dibawa ke Klinik Hewan Universitas Brawijaya untuk dilakukan pemeriksaan.

\section{c. Gejala Klinis}

Gejala klinis yang tampak diantaranya discharge berwarna kucing bilateral pada mata kanan dan kiri, kornea keruh bilateral, chemosis bilateral. Kucing masih sangat terlihat aktif.

\section{d. Pemeriksaan Fisik}

Pada pemeriksaan kondisi umum kucing "blacky" menunjukkan kondisi gizi malnutrisi, terdapat pot belly pada inspeksi visual abdomen. Kondisi integument menunjukkan adanya alopecia ditelinga kanan dan kaki kanan, sebagian pada ventral abdomen, rambut kusam, berdiri, dan jarang. Pemeriksaan hidung, telinga, mulut, cardiovascular, musculoskeletal, genital, abdomen, nervus, pheripheral lymph nodes, dan respirasi tidak ada kelainan. Namun pada pemeriksaan mata kucing blacky ditemukan kelainan.

\section{e. Tahapan Pemeriksaan Mata}

Dalam pemeriksan mata pengambilan history pasien secara lengkap merupakan hal terpenting dan sangat dibutuhkan pada setiap pemeriksaan. Pengambilan history pasien melitputi ras, umur, kondisi umum termasuk nafsu makan, defekasi, urinasi, riwayat vaksinasi, riwayat penyakit kulit, infestasi ektoparasit, serta penyakit lainnya. Dilakukan 
pencatatan terhadap keluhan utama "ocular discomfort", lama penyakit, progesivitas, riwayat penyakit mata sebelumnya, dan terapi yang sudah pernah diberikan. Selanjutnya dilakukan pemeriksaan at the distance pada kedua mata dalam jarak tertentu meliputi kesimetrisan kedua bola mata dan analisi posisi mata yang bermasalah. Tes visualisasi meliputi berbagai macam tes diantaranya manace test, fixation visual test, placing visual test, pupillary light reflex (PLR), dazzle reflex test, obstacle course. Pemeriksaan selanjutya yaitu up closed dari mata bagian depan ke belakang. Dilakukakan identifikasi lokasi dan lesion, selanjutnya menentukan tes yang sesuai dengan masalah. Hasil pemeriksaan mata kucing Blacky dapat dilihat pada Tabel.1

\section{f. Diagnosa Penunjang}

Pemeriksaan penunjang yang digunakan dalam peneguhan diagnosa pada kasus kali ini adalah Schirmer Tear Test (STT) dan Fluorescein Test.

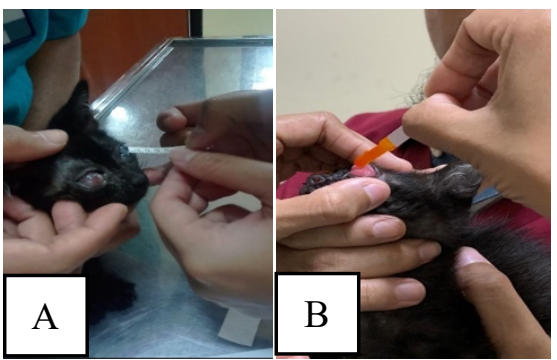

Gambar 2. Pemeriksaan mata dengan menggunakan Schirmer Tear Test (STT) (A), dan pemeriksaan mata dengan menggunakan fluorescein test (B) (dokumentasi pribadi, 2020).

\section{g. Diagnosa Banding}

Diagnosa banding dari kasus ini adalah corneal ulser, glaucoma, tumor mata, squamous cell carcinoma, prolapsus bulbi, bupthalmic os traumatic, opthalmia neonatorum.

h. Diagnosa dan Prognosa

Diagnosa yang dapat diambil pada kasus kali ini adalah Cornea ulcer karena Secondary Trauma Keratoconjuntivitis Sicca dan prognosanya adalah dubius.

\section{i. Terapi}

Terapi yang diberikan yaitu dengan flushing $\mathrm{NaCl}$ fisiologis, antibiotic tetes Cravit (Levofloksasin) sebanyak 6 kali sehari sebanyak 1 tetes pada kedua mata, obat tetes Pilokarpin $\mathrm{HCl}$ 1\% pada mata kanan 6 kali sehari sebanyak 1 tetes, obat tetes mata yang mengandung Hydroxypropyl methylcellulose, dan obat cacing 
Tabel 1. Hasil Pemeriksaan Fisik Mata

\begin{tabular}{|c|c|c|c|}
\hline Mata & Kanan & Kiri & Keterangan \\
\hline Palpebrae inferior & $\begin{array}{l}\text { Utuh, tidak } \\
\text { ada luka, } \\
\text { bengkak }\end{array}$ & $\begin{array}{l}\text { Utuh, tidak ada } \\
\text { luka, bengkak }\end{array}$ & \\
\hline Palpebrae superior & $\begin{array}{l}\text { Utuh, tidak } \\
\text { ada luka, } \\
\text { bengkak }\end{array}$ & $\begin{array}{l}\text { Utuh, tidak ada } \\
\text { luka, bengkak }\end{array}$ & \\
\hline Refleks palpabrae & $\begin{array}{l}\text { Tidak terdapat } \\
\text { reflek palpebrae }\end{array}$ & $\begin{array}{c}\text { Terdapat reflek } \\
\text { palpebrae }\end{array}$ & \\
\hline Cilia & $\begin{array}{l}\text { berada di } \\
\text { palpebrae }\end{array}$ & $\begin{array}{l}\text { Setengah cilia } \\
\text { mata kiri } \\
\text { melengkung ke } \\
\text { dalam }\end{array}$ & \\
\hline konjungtiva & Warna merah & Warna merah & $\begin{array}{c}\text { Terdapat chemosis } \\
\text { bilateral }\end{array}$ \\
\hline Inferior & Ada inflamasi & Ada inflamasi & \\
\hline Superior & Ada inflamasi & Ada inflamasi & \\
\hline Bulbar & Ada inflamasi & Ada inflamasi & \\
\hline membran niktitan & Terlihat & terlihat & Terlihat bilateral \\
\hline Sklera & Tidak terlihat & Tidak terlihat & \\
\hline Kornea & Keruh & keruh & \\
\hline Pupil & Tidah terlihat & Tidak terlihat & \\
\hline Iris & Tidak terlihat & Tidak terlihat & \\
\hline Lensa & Tidak terlihat & Tidak terlihat & \\
\hline Vasa injection & Terlihat & terlihat & $\begin{array}{l}\text { Vasodilatasi pembuluh } \\
\text { darah pada konjungtiva }\end{array}$ \\
\hline Limbus & Tidak terlihat & Tidak terlihat & \\
\hline Kesimetrisan mata & Lebih besar & normal & Simetris \\
\hline Posisi bola mata & $\begin{array}{l}\text { Lebih menonjol } \\
\text { ke depan }\end{array}$ & $\begin{array}{l}\text { Pada cavum } \\
\text { orbita }\end{array}$ & $\begin{array}{l}\text { Mata kanan terkesan } \\
\text { exophthalmus }\end{array}$ \\
\hline Manace test & \multicolumn{2}{|l|}{ Tidak ada reflek } & $\begin{array}{c}\text { Tidak ada reflek } \\
\text { berkedip }\end{array}$ \\
\hline Fixation visual test & \multicolumn{2}{|c|}{ Tidak ada respon } & $\begin{array}{l}\text { Tidak ada respon } \\
\text { menundukkan }\end{array}$ \\
\hline
\end{tabular}




\begin{tabular}{|c|c|c|c|}
\hline & & & $\begin{array}{c}\text { kepala atau } \\
\text { mengikuti } \\
\text { pergerakan "cotton } \\
\text { wool ball" }\end{array}$ \\
\hline Placing visual test & \multicolumn{2}{|c|}{ Tidak ada respon } & $\begin{array}{l}\text { Tidak ada respon } \\
\text { mencapai meja dengan } \\
\text { kaki }\end{array}$ \\
\hline Pupilary Light Reflex & \multicolumn{2}{|c|}{ Tidak dilakukan } & Tidak dilakukan \\
\hline Dazzle & $\begin{array}{l}\text { Tidak } \\
\text { Terdapat } \\
\text { reflek }\end{array}$ & Ada reflek sedikit & $\begin{array}{c}\text { Mata kiri memicing } \\
\text { sedikit ketika diberikan } \\
\text { sinar terang secara tiba- } \\
\text { tiba }\end{array}$ \\
\hline Obstacle course & \multicolumn{2}{|c|}{ Tidak dilakukan } & Tidak dilakukan \\
\hline Fluorescein test & + & + & $\begin{array}{c}\text { warna hijau pada } \\
\text { lapisan kornea }\end{array}$ \\
\hline $\begin{array}{l}\text { Schirmer Tear Test } \\
\text { (STT) }\end{array}$ & $10 \mathrm{~mm}$ & $8 \mathrm{~mm}$ & $\begin{array}{c}\text { Nilai STT yang dibawah } \\
\text { normal }\end{array}$ \\
\hline
\end{tabular}

\section{HASIL DAN PEMBAHASAN}

Kornea merupakan struktur transparan yang menyerupai kubah, merupakan pembungkus dari iris dan pupil berfungsi membantu memfokuskan cahaya. Pupil merupakan daerah hitam ditengahtengah iris. Iris merupakan jaringan berwarna yang berbentuk cincin, menggantung dibelakang kornea dan didepan lensa yang berfungsi mengatur jumlah cahaya yang masuk kemata dengan cara merubah ukuran pupil. Lensa merupakan struktur cembung ganda yang tergantung diantara humor aqueus dan vitreus yang berfungsi membantu memfokuskan cahaya ke retina. Retina merupakan lapisan jaringan peka cahaya yang terletak dibagian belakang bola mata yang berfungsi mengirimkan pesan visual melalui saraf optikus ke otak. Saraf optikus merupakan kumpulan jutaan serabut saraf yang membawa pesan visual dari retina ke otak. Aqueus humor merupakan cairan jernih dan encer yang mengalir diantara lenda dan kornea (mengisi segmen anterior mata) yang dihasilkan oleh prosesus siliaris, serta merupakan sumber makanan bagi lensa dan kornea. Vitreus humor merupakan gel transparan yang terdapat dibelakang lensa dan didepan retina (mengisi segmen posterior mata) (Slatter, 2008).

Lesi pada kornea dapat terjadi ketika kelopak mata gagal melindunginya dari luar, kegagalan dari kornea untuk tetap lembab, atau adanya infeksi dari dalam. Umumnya lesi pada kornea meliputi abrasi atau ulcer, berupa kehilangan jaringan epithelnya. Lesi yang lebih mendalam, 
seperti laserasi atau penetrasi, bisa menyebabkan bakteri, fungi, atau bendabenda asing menginfeksi kornea itu sendiri. Berbagai gejala klinis yang umumnya menyertai lesi dari kornea meliputi ketidakmampuan kelopak mata untuk terbuka (blepharospasm), lakrimasi yang disertai dengan keluarnya air mata (epiphora), menghindari cahaya (photophobia), bola mata agak kedalam (endophthalmos), yang dapat diikuti dengan kongesti atau hiperemi bagian konjungtiva, edema konjungtiva (chemosis), pupil mengalami pengecilan (miosis). Kornea yang mengalami edema yang disertai vaskularisasi merupakan tanda kornea yang mengalami peradangan (keratitis) (Stanley, 2007).

Berdasarkan hasil anamnesa dan pemeriksaan mata yang telah dilakukan dengan melihat kondisi kornea yang keruh bilateral, iris dan pupil tidak terlihat akibat kekeruhan sehingga test PLR tidak dapat dilakukan, exophthalmic unilateral, chemosis bilateral, maka dokter hewan menyarankan untuk melakukan pemeriksaan schirmer tear test (STT), pemeriksaan nictitan membrane, dan fluorescein test. Schirmer Tear Test (STT) salah satu metode yang digunakan untuk mendiagnosa dry eye syndrome. Kondisi ini terjadi akibat kelenjar air mata tidak dapat menghasilkan cukup air mata untuk menjaga kelembapan pada mata. Akibatnya, mata tidak bisa menangkal zat iritan dari luar seperti debu, sehingga mata menjadi merah, ada rasa sakit seperti terbakar dan seperti ada sensasi stinging (tersengat) atau perih. Gejala dry eye syndrome salah satunya adalah penglihatan menjadi kabur. Schirmer Tear Test menggunakan kertas absorben untuk mengukur jumlah air mata yang keluar selama satu menit. Nilai normal dari STT pada anjing dan kucing adalah $>15 \mathrm{~mm}$. Jika kurang maka mengindikasikan hewan peliharaan kita menderita mata kering (Dry Eye) (Ilyas, 2012).

Hasil penekanan didapat konsistensi mata kanan yang keras disertai dengan hadirnya discharge berlebih di sekitar mata, sehingga mata kanan dan kiri kucing dinyatakan mengalami corneal ulcer, dibuktikan dengan pemeriksaan fluorescein test dimana warna hijau paper strip masih menempel pada mata meskipun sudah dibasuh menggunakan $\mathrm{NaCl}$. Nilai STT pada mata kanan didapatkan $10 \mathrm{~mm} /$ menit dan STT mata kiri $8 \mathrm{~mm} /$ menit. Nilai tersebut termasuk dalam katagori tidak normal, karena berdasarkan penelitian Rajaei et al. (2019), normal STT pada kucing pada umumnya rata-rata adalah $14,9 \pm 4,8 \mathrm{~mm} /$ menit, hal tersebut tergantung pada umur, jenis kelamin, dan ras. Pada kucing betina nilai STT $15,1 \pm 4,5 \mathrm{~mm} /$ menit, sedang kucing jantan 14,5 $\pm 5.0 \mathrm{~mm} /$ menit. Pada kucing ras domestic short hair (DSH) nilai 
STT sebesar 14,6 $\pm 5.0 \mathrm{~mm} /$ menit, sedangkan pada kucing Persia 16,5 $\pm 3.1 \mathrm{~mm} /$ menit. Berdasarkan pemeriksaan STT kucing "Blacky" mendapatkan hasil dibawah nilai normal pada mata kiri, sehingga dapat disimpulkan bahwa kucing "Blacky" mengalami corneal ulcer karena secondary trauma keratoconjuntivitis sicca.

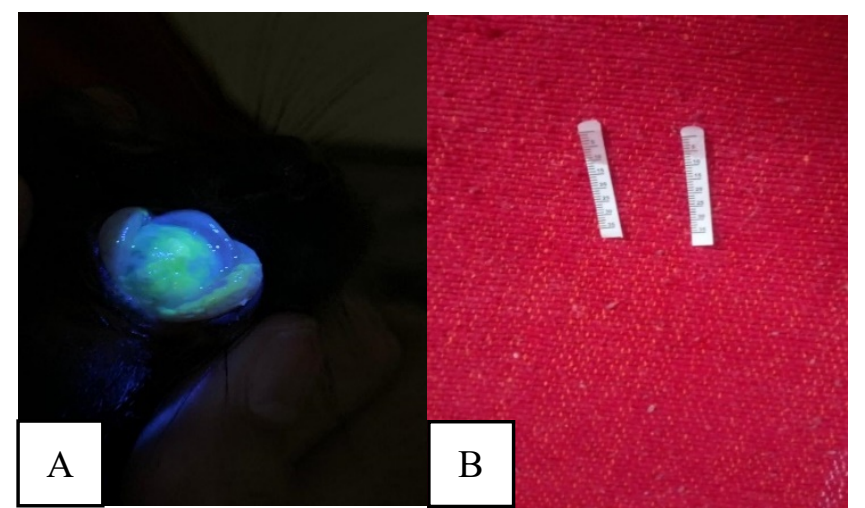

Gambar 3. Hasil pemeriksaan fluorescein test (A), dan schirmer test (B)

Fluorescein Test adalah tes yang menggunakan pewarna orange (fluorescein) dan cahaya biru untuk mendeteksi benda asing di mata. Tes ini juga dapat mendeteksi kerusakan pada epitel kornea, permukaan luar mata. Prinsip kerja dari Fluorescein test adalah Zat warna fluoresin akan berubah hijau pada media alkali. Zat warna fluoresin bila menempel pada epitel kornea yang defek akan memberikan warna hijau karena jaringan epitel yang rusak bersifat lebih basa. Intepretasi bila terdapat warna hijau pada kornea berarti terdapat defek pada epitel kornea. Defek ini dapat dalam bentuk erosi kornea atau infiltrate yang mengakibatkan kerusakan epitel (Ilyas, 2009).

Terapi yang diberikan yaitu dengan flushing $\mathrm{NaCl}$ fisiologis, antibiotic tetes Cravit (Levofloksasin) sebanyak 6 kali sehari sebanyak 1 tetes pada kedua mata, obat tetes Pilokarpin $\mathrm{HCl}$ 1\% pada mata kanan 6 kali sehari sebanyak 1 tetes, obat tetes mata yang mengandung Hydroxypropyl methylcellulose, dan obat cacing pirantel pamoat dengan dosis $10 \mathrm{mg} / \mathrm{kg}$ secara peroral. Flushing $\mathrm{NaCL}$ pada mata kanan dan kiri yang bertujuan untuk membersihkan mata dari discharge, diberikan sesaat sebelum diberikan terapi obat tetes. Pemberian obat tetes mata yang mengandung antibiotik levofloksasin diberikan enam kali sehari sebanyak 1 tetes pada kedua mata. Pada mata kanan diberikan pilocarpin HCL 1\% untuk menurunkan tekanan intra okuler, diteteskan hanya pada mata kanan satu tetes sebanyak enam kali sehari, dengan pemberian 10 menit sebelum pemberian antibiotik tetes. Serta pemberian tetes mata buatan yang mengandung Hydroxypropyl methylcellulose diberikan pada kedua mata sebanyak enam kali sehari untuk menambah visikositas.

Levofloksasin adalah bentuk (S)enansiomer yang murni dari campuran rasemat ofloksasin. Levofloksasin aktif terhadap bakteri gram positif dan negatif, termasuk bakteri anaerob. Mekanisme kerja 
levofloksasin yang utama adalah melalui penghambatan DNA gyrase bakteri (DNA topoisomerase II), sehingga terjadi penghambatan replikasi dan transkripsi DNA (Abchi, et al. 2018). Pilokarpin adalah amina tersier langsung bertindak parasympatomimetic yang memiliki efek asetilkoin muscarinic. Setelah penggunaan obat tetes mata, miosis terjadi pada sekitar 10 sampai 30 menit dan berlangsung 4 sampai 8 jam semestara pengurangan puncak tekanan intra ocular terjadi dalam 75 menit dan pengurangan biasanya berlangsung selama 4 sampai 14 jam (Novita, 2014). Hydroxypropyl methylcellulose (HPMC) merupakan polimer mukoadhesif yang larut air sehingga meningkatkan visikositas mata dan banyak digunakan sebagi komponen artificial tears atau tetes air mata buatan. Terapi lainnya seperti pemberian obat cacing pirantel pamoat dengan dosis $10 \mathrm{mg} / \mathrm{kg}$ secara peroral kemudian di ulang kembali 3 bulan sekali sebagai treatment untuk pencegahan terhadap kasus cacingan pada hewan.

Ulkus kornea (corneal ulcer) adalah kerusakan yang terjadi pada permukaan kornea. Corneal ulcer biasanya disebabkan oleh trauma pada kornea, infeksi (Feline herpes virus), kurangnya sekresi air mata (Ceratoconjunctivitis sicca), dan kelainan rambut mata (Enteropion). Corneal ulcer biasnya ditandai dengan gejala sakit yang sangat pada daerah mata dikarenakan permukaan kornea dipenuhi saraf-saraf reseptor, fotofobia dikarenakan terjadinya peradangan yang tidak nyaman dimata, menyipitkan mata, conjunctiva dan sklera memerah, dan warna kornea menjadi keruh keputihan.

Keratoconjuntivitis Sicca merupakan kelainan pada mata yang terjadi akibat kekurangan produksi cairan air mata sehingga mata menjadi kering (dry eye, xerophthalmia) dan umumnya penyakit ini bersifat kronis. Ada beberapa tipe penyakit ini yaitu keratokonjungtivitis akibat tipe 1 dan tipe 2 . Keratokonjungtivitis tipe 1 berupa kekurangan sekresi dari kelenjar lakrimalis atau kelenjar lakrimalisnya mengalami atropi. Keratokonjungtivitis tipe 2 menyebabkan terjadinya kerusakan glandula lakrimalis yang sering terjadi pada kasus distemper pada anjing, trauma kelenjar lakrimalis atau tidak adanya suplai saraf pada kelenjar tersebut, penyumbatan pada ductus dari kelenjar lakrimalis karena infeksi bakteri kronis pada konjungtiva dan reaksi radang berperantara imun.

Keratoconjunctivitis sicca (KCS), yang lebih dikenal sebagai dry eye, adalah kondisi dimana terjadi peradangan pada permukaan mata yang disebabkan oleh penurunan patologis pada komponen aqua dari membran air mata. Kondisi ini sering terjadi pada anjing dan kucing, yang dimana hasil Schirmer Tear Test (STT) kurang dari 10 mm/menit (Gelatt, et al., 1976). Menurut 
Williams (2014) bahwa pada anjing dan kucing, penilaian produksi air mata umumnya sederhana yaitu dengan Schirmer Tear Test yang diletakkan dibagian kantung konjungtiva selama satu menit yang hasil tes tersebut setidaknya sebesar $15 \mathrm{~mm}$, dan apabila hasil yang didapatkan kurang maka dikhawatirkan adanya KCS, dan pemeriksaan fisik mata juga dapat diperlukan untuk menentukan diagnosanya. KCS dapat dibagi menjadi dua jenis, yaitu di mana produksi air mata kurang, dan pada kasus lain di mana penguapan air mata menyebabkan defisiensi air mata permukaan mata. DES neurogenik dapat terjadi akibat disfungsi saraf aferen (trigeminal nerve) dan/atau eferen (parasimpatis/simpatis) kelenjar lakrimal tetapi terutama terkait dengan disfungsi parasimpatis pada anjing (Matheis et al., 2012). DES neurogenik telah dilaporkan hanya pada kucing dengan disautonomia (Kidder et al., 2008).

Menurut Williams (2014) gejala utama pada kasus dre eye adalah tidak adanya kepekaan pada permukaan mata, dan yang paling terpenting, pantulan cahaya yang diarahkan ke kornea tidak tidak memiliki batas yang tajam melainkan dipecah menjadi banyak titik kecil. Membran air mata normal di atas permukaan kornea memberikan pantulan yang jernih. Gejala lain dari dry eye yaitu konjungtiva terlihat kemerahan dan adanya discharge mukoid hingga mukosa-purulen pada mata. Gejala kemerahan pada konjungtivitis sehingga terlihat tidak hanya pada globe itu sendiri, tetapi juga pada konjungtiva. Kantung konjungtiva bagian bawah dapat terlihat hiperemik hanya karena adanya debris bergerak ke dalamnya dari permukaan mata dan untuk menilainya dapat dilakukan dengan menarik bagian kelopak mata bagian atas dengan perlahan.

Hal tersebut penting dilakukan dalam membedakan kasus konjungtivitis dari uveitis, yang dimana konjungtivitis akan melibatkan konjungtiva dari kedua globe dan kelopaknya, sedangkan radang intraokuler uveitis akan menyebabkan hiperemia pada episclera di seluruh mata, dan khususnya di belakang limbus yang merupakan tempat kornea bertemu sklera, karena area ini menutupi ciliary body. Kemerahan ini dikenal sebagai ciliary flush. Hal penting lainnya yang perlu diperhatikan tentang kemerahan pada mata akibat peradangan adalah hiperemia dimana kemerahan yang menyebar tersebut berasal dari sitokin yang meresap melalui jaringan, sementara pada glaukoma, kemerahan pada mata berasal kongesti vaskular pada pembuluh darah episkleral. Jadi pada hipertensi okuler sklera antara pembuluh episkleral yang membesar akan berwarna putih.. 
Beberapa faktor menunjukkan adanya gangguan fungsi saraf adalah kemungkinan penyebab DES (dry eye syndrome) pada kucing, seperti adanya penurunan sensitivitas kornea, meningkatnya lakrimasi sebagai respon terhadap noxious olfactory stimulus, respon terhadap terapi parasimpatomimetik, kurangnya respon terhadap terapi imunomodulator yang diketahui efektif pada manusia dan anjing dengan immunemediated dacryoadenitis, dan kurangnya bukti histologis dari patologi kelenjar lakrimal cukup untuk menjelaskan disfungsi imunemediasi. Sensitivitas kornea yang berkurang, histologi kelenjar lakrimal normal, meningkatnya nilai STT pada mata setelah stimulasi refleks nasolakrimal dan peningkatan nilai STT sebagai respons terhadap terapi pilocarpine semuanya menunjukkan bahwa kelenjar lakrimal dan persarafan parasimpatis mempertahankan fungsi, dan hipoestesia kornea sebagian besar atau bertanggung jawab penuh atas DES.

Terapi yang diberikan untuk mengurangi tingkat keparahan penyakit mata blacky memberikan respon yang lumayan bagus ditandai dengan mengecilnya palpebrae dan konjungtiva secara perlahan, namun chemosis masih terlihat setelah terapi minggu ke-1. Kondisi diperparah ketika mata kucing Blacky dicakar oleh kucing lainnya sehingga menambah keparahan kondisi matanya yang ditunjukan pada Gambar 4(B). Terapi tetap dilanjutkan hingga minggu ke-3 dan didapatkan respon kesembuhan yang baik ditandai dengan sudah tidak terlihat chemosis dan membran niktitan, produksi discharge mata berkurang, sudah terdapat respon palpebrae pada mata kiri namun pada mata kanan hanya ada sedikit. Respon palpebrae ditandai dengan mata kiri sudah mampu membuka dan menutup, namun kornea masih terlihat keruh bilateral. Lesi pada kornea sebelah kanan sudah mengecil, ukuran bola mata kanan mengecil. Hasil STT menunjukkan pada mata kanan adalah 15 $\mathrm{mm}$ dan mata kiri $14.5 \mathrm{~mm}$. Progres kesembuhan setelah dilakukan terapi hingga minggu ke-3 terlihat berdasarkan mengecilnya bola mata sebelah kanan dan berkurangnya peradangan pada kedua mata kucing Blacky yang terlihat pada Gambar 4, hal tersebut juga sebanding dengan berkurangnya ulcer serta kembali meningkatnya produksi air mata yang dapat dilihat pada Gambar 5.

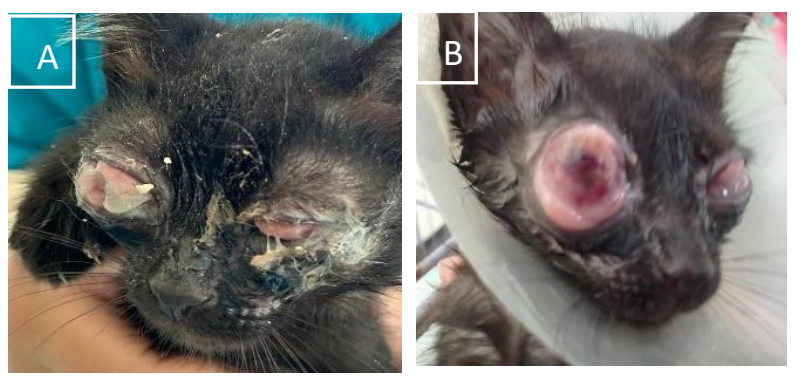




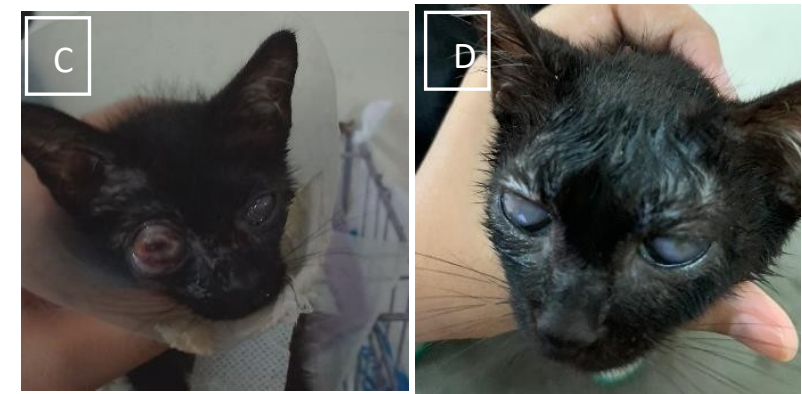

Gambar 4. Progres kesembuahan kucing Blacky minggu ke-1 (A \& B), Minggu ke-2 (C), Minggu ke-3 (D)
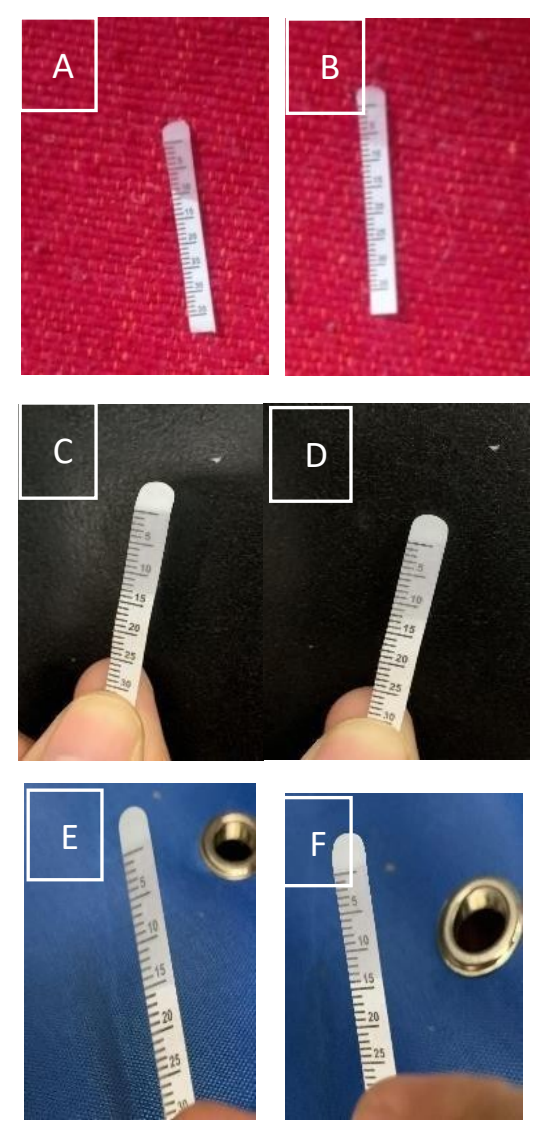

Gambar 5. Hasil STT minggu ke-1 (kanan $10 \mathrm{~mm} \&$ kiri $8 \mathrm{~mm}$ ) (A\&B), minggu ke-2

(Kanan $13 \mathrm{~mm} \&$ kiri $12 \mathrm{~mm}$ ) (C\&D), minggu ke-3 (Kanan $15 \mathrm{~mm} \&$ kiri $14.5 \mathrm{~mm}$ )

$(\mathrm{E} \& \mathrm{~F})$

\section{KESIMPULAN}

Berdasarkan kasus yang ditemukan bahwa kucing "Blacky" mengalami corneal ulcer karena secondary trauma keratoconjuntivitis sicca. Progres terapi menunjukkan adanya perbaikan dimana ukuran mata sebelah kanan mengecil, lesi pada kornea mata mengecil yang terlihat berdasarkan pemeriksaan fluorescein test, dan menurunnya peradangan pada kedua mata kucing "Blacky", serta adanya perbaikan produksi air mata yang diamati berdasarkan nilai schimmer tear test (STT).

\section{UCAPAN TERIMA KASIH}

Terimakasih kepada seluruh staff Rumah Sakit Hewan Pendidikan dan Klinik Hewan Universitas Brawijaya atas bantuan dan kerjasama untuk penyelesaian Laporan ini.

\section{DAFTAR PUSTAKA}

Abchi, Faris T., Found K., Mohammad and Amar Baba. 2018. Formulation and Stability Studies of Levofloxacin 0.5\% Eye Drops. Department of Physiology, Biochemistry and pharmacology, College of Veterinary Medicine, University of Mosul, Iraq.

Gelatt, K.N., Peiffer R.L. Jr., Erickson J.L., et al. Evaluation of tear formation in the dog, using a modification of the Schirmer tear test. J Am Vet Med Assoc 1975;166:368-70.

Ilyas, S., Yullianti, S.E., Fluoresein. 2012. Ilmu Penyakit Mata. Edisi IV, cetakan ke-2. 
Badan Penerbit Fakultas

Kedokteran Universitas Indonesia.

Ilyas, S., Fluoresein. 2009. Dasar Teknik Pemeriksaan Dalam Ilmu Penyakit Mata. Edisi III, cetakan ke-1. Fakultas Kedokteran Universitas Indonesia.

Kidder, A.C., Johannes C., O'Brien D.P., et al. Feline dysautonomia in the Midwestern United States: a retrospective study of nine cases. J Feline Med Surg 2008; 10: 130-136.

Matheis, F.L., Walser-Reinhardt L., and Spiess B.M. Canine neurogenic keratoconjunctivitis sicca: 11 cases (2006- 2010). Vet Ophthalmol 2012; 15: 288-290.

Novita, M. 2018. Sediaan Tetes Mata Miotik Pilokarpin HCL. Fakultas Farmasi. Universitas Pancasila: Jakarta.
Slatter, D. H., Maggs, D. J, Miller, P. E., Ofri, R. 2008. Slatter's fundamentals of veterinary ophthalmology. 4 th ed. St. Louis, Mo.: Saunders Elsevier.

Stanley, R.G. 2007. Management of corneal ulcers in small animals. Proceedings of Animal Veterinary Association: Australia.

Rajaei, S.M, Faghihi H., Williams D.L., and Aftab G. 2019. Evaluation of Tear Production Using the Schimmer Tear Test I in Healty Cats: Efect of age, Life Stage, Sex, Breed, And Neuter. British Medical Journal Vol.184(26):799.

Williams, David L. 2014. Obvious Ophthalmology: Keratoconjunctivitis Sicca. VETcpd - Ophthalmology. Vol 1 - July 2014. 